\title{
Recommendations for Effective and Sustainable Regulation of Biopesticides in Nigeria
}

\author{
Christine Abey Ashaolu 1,2,*, Chibuzor Onyinye Okonkwo ${ }^{2,3}{ }^{\mathbb{D}}$, Elizabeth Njuguna ${ }^{2} \mathbb{D}$ and Dennis Ndolo ${ }^{2}$
}

Citation: Ashaolu, C.A.; Okonkwo, C.O.; Njuguna, E.; Ndolo, D.

Recommendations for Effective and Sustainable Regulation of

Biopesticides in Nigeria.

Sustainability 2022, 14, 2846

https://doi.org/10.3390/su14052846

Academic Editor:

Helvi Heinonen-Tanski

Received: 25 December 2021

Accepted: 2 February 2022

Published: 1 March 2022

Publisher's Note: MDPI stays neutral with regard to jurisdictional claims in published maps and institutional affiliations.

Copyright: (C) 2022 by the authors. Licensee MDPI, Basel, Switzerland. This article is an open access article distributed under the terms and conditions of the Creative Commons Attribution (CC BY) license (https:// creativecommons.org/licenses/by/ $4.0 /)$.
1 Chemical Evaluation and Research Directorate, National Agency for Food and Drug Administration and Control (NAFDAC), Federal Capital Territory, Abuja 900287, Nigeria

2 Biopesticides Group, International Centre for Genetic Engineering and Biotechnology (ICGEB), Observatory, Cape Town 7925, South Africa; oko210@unical.edu.ng (C.O.O.); elizabeth.njuguna@icgeb.org (E.N.); ndolo@icgeb.org (D.N.)

3 Department of Biochemistry, Faculty of Basic Medical Sciences, University of Calabar, Calabar 540271, Nigeria

* Correspondence: christine.ashaolu@nafdac.gov.ng or ashaolulincon@yahoo.com; Tel.: +234-8-05077-7634

\begin{abstract}
The global trend towards increased demand for organic food, greener environments, and the integration of biological control agents into pest management strategies has greatly enhanced the need for biopesticides. Biopesticides are made from micro-organisms or other natural substances and are, hence, generally environmentally friendly. However, despite their great potential-and in part due to regulatory challenges-relatively few biopesticides have been registered and commercialised in Nigeria compared to other African countries, such as South Africa and Kenya. Biological active agents are so diverse that applying the same safety standards to all of them is almost impossible. A comparative review of risk assessment processes of Nigeria's biopesticide regulations with other developing African countries (South Africa and Kenya) and developed regions (the European Union and the United States of America) was conducted. Prolonged field testing, lack of bridged risk assessments, and technical checklists were identified as key factors hampering the research and development of biopesticides in Nigeria. Suitable amendments to the existing regulations guiding biopesticide formulation and utilisation in Nigeria are recommended. Risk assessment matrices for microbial and biochemical pesticides and a scientific/technical checklist have also been developed. It is apparent that harmonisation and data exchange among countries in the region could enhance the advancement of scientific and technical knowledge for sustainable regulation of, and cross-border trade in, biopesticides.
\end{abstract}

Keywords: biopesticides; regulations; risk assessment; regulatory challenges; sustainability; Nigeria

\section{Introduction}

It has always been necessary to protect plants from pests and pathogens to provide the human population with quality and sufficient food. Conventional synthetic pesticides have been used effectively over the years to ensure food safety and security. However, there has, over the last few years, been a global drive towards more organic food production and greener environments-and consequently, a strong push for the integration of biopesticides into pest management strategies [1].

There is no single, internationally agreed-upon definition for biopesticides. The Food and Agriculture Organisation (FAO) describes biopesticides as products with active substances that are based on botanicals, semiochemicals, or microbials [2]. The Organisation for Economic Cooperation and Development (OECD) refers to biopesticides as biocontrol agents that include microbials, pheromones, and other semiochemicals and invertebrates [3]. Despite the great potential of these products, the associated regulatory processes for their authorisation are generally lengthy, time-consuming, and costly [4]. Disproportionate data requirements associated with extended assessment processes can present a 
significant challenge that deters biopesticide companies from applying for registration in some jurisdictions [5].

Ideally, regulations should not be an obstacle to the development and commercialisation of biopesticides, but rather a scientific tool or process to ensure safety of environment, human, and animal health. The different definitions and classifications of biopesticides, with variations in data requirements and regulatory frameworks, remain an issue of concern for biopesticide research and development. While some countries or regions (e.g., European Union (EU)) have adopted the conventional pesticide regulatory models for the regulation of biopesticides [6], others have customised regulations (e.g., Nigeria and the United States of America (USA)).

The fact that biologically active agents are so diverse makes it almost impossible for regulators to apply the same consumer safety criteria or environmental conditions to all of them [7]. The issue of multiple modes of action is one of the concerns related to the regulation of biopesticides [8]. For example, even though Trichoderma species are used as biopesticides against soil-borne plant pathogenic fungi [9], they are also known to enhance the absorption of micro- and macronutrients from the soil [10]. They also function as cell wall degrading enzymes, parasitise plant pathogenic fungi, and also produce antibiotics $[9,11]$. Fluorescent Pseudomonas can also be used as both biocontrol agents as well as plant growth promoting agents [12]. The OECD is making concerted efforts to promote harmonised data requirements. This action will enable companies to easily submit applications for registration and, on the other hand, create a mutually beneficial platform for regulatory agencies to benefit from each other [13].

The National Agency for Food and Drug Administration and Control (NAFDAC) is the national regulatory authority responsible for regulating biopesticides in Nigeria. Prior to the licensing of any biopesticide product in Nigeria, NAFDAC conducts technical and documentary regulatory reviews to ensure the safety and efficacy of the product. However, despite the availability of regulatory procedures, and the interest to promote the development and commercialisation of biopesticides, only a few have been registered in Nigeria, compared to other African countries, such as South Africa and Kenya (Figure 1). This may be due to the requirement for extensive field testing and screening procedures, inadequate risk assessment techniques, and low public awareness.

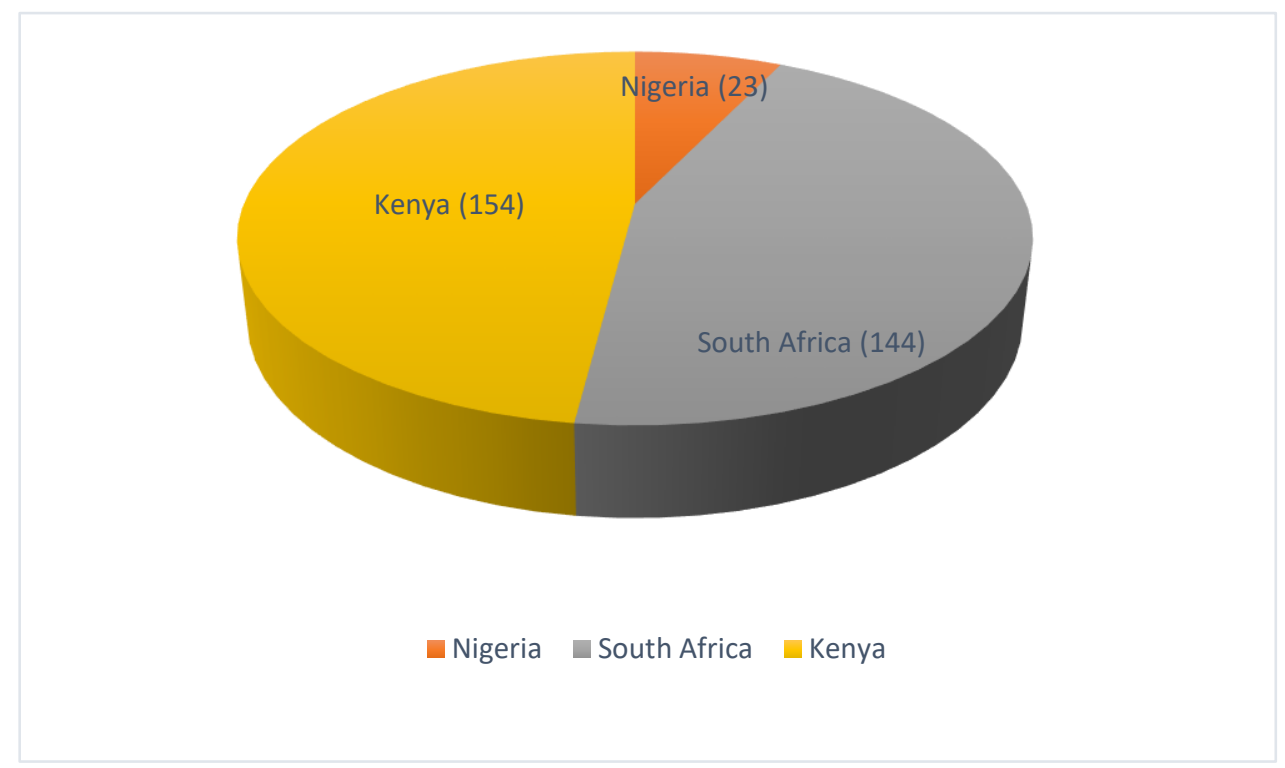

Figure 1. Registered biopesticides (as at July 2021) in Nigeria [14], South Africa [15], and Kenya [16].

The objective of this study was to review Nigeria's biopesticide regulatory system and make recommendations to facilitate the development of a more sustainable regulatory approach to enhance their development and commercialisation. 


\section{Regulatory Challenges to Biopesticide Registration}

Assessment of the safety and efficacy of a biopesticide product is an essential prerequisite for its authorisation. However, many investors view regulatory oversight as an impediment to the timely development and commercialisation of their products. The extended field trials and risk assessments conducted (usually over two different growing seasons) are seen as a key challenge for the research and development of biopesticide products. A further challenge is the multiplicity of modes of action of certain microorganisms. This often leads to regulators requiring a lot of data to enable them to better establish safety and efficacy criteria for these products. In addition, most applicants who intend to register Plant Incorporated Protectants (PIPs) as biopesticides do not often return to finalise their registration process. This is probably due to their inability to comply with the relevant GMO safety assessments at the responsible Biosafety Agency (e.g., the National Biosafety Management Agency in the case of Nigeria). The successful commercialisation of biopesticides after registration is also another major challenge for investors. Biopesticides are expected to compete with existing conventional pesticides in terms of cost, market acceptability, and mode of action. Compared to biopesticides, conventional pesticides have been on the market for decades-and are thus well known to the public and less expensive. They also have a faster mode of action, compared to biopesticides. Political, social, and societal pressures also pose a significant challenge to the effective marketing of biopesticide products in Nigeria.

\section{Methodology}

To achieve the objectives of this research, three distinct, but related, strategies were employed.

i. Comparative assessment of biopesticide regulations:

A comparative assessment of the Nigeria biopesticide regulations versus those of select African developing countries (South Africa and Kenya) and developed regions (EU and USA) were carried out. This was done to identify regulatory gaps and, consequently, make recommendations to improve the Nigerian biopesticides regulatory system. The available online biopesticide-related regulations with summary of the assessments for each of the countries and regions are shown in Table 1.

Table 1. Overview of the regulatory framework comparison between EU, USA, South Africa, Kenya, and Nigeria.

\begin{tabular}{|c|c|c|c|c|c|}
\hline \multirow[t]{2}{*}{ Indicators } & \multicolumn{5}{|c|}{ Regulatory Frameworks } \\
\hline & EU & USA & South Africa & Kenya & Nigeria \\
\hline $\begin{array}{l}\text { Biopesticide } \\
\text { Regulations }\end{array}$ & $\begin{array}{l}\text { Regulation (EC) N0. } \\
1107 / 2009 \text { [17] }\end{array}$ & 40 CFR Part 158 [18] & $\begin{array}{l}\text { Guidelines for } \\
\text { Registration of } \\
\text { Biological } \backslash \text { Agricultural } \\
\text { Remedies in South } \\
\text { Africa 2015 [19] }\end{array}$ & $\begin{array}{l}\text { Pest Control Products } \\
\text { Act [Act No. } 4 \text { of } \\
\text { 1982, L.N. } 89 / 1983, \\
\text { Act No. } 6 \text { of } \\
\text { 2009) [20] }\end{array}$ & $\begin{array}{l}\text { Biopesticide } \\
\text { Registration } \\
\text { Regulations 2019 [21] }\end{array}$ \\
\hline Authorities & EC, EFSA RMS & USEPA & DALRRD & РСРВ & NAFDAC \\
\hline
\end{tabular}


Table 1. Cont.

\begin{tabular}{|c|c|c|c|c|c|}
\hline \multirow[t]{2}{*}{ Indicators } & \multicolumn{5}{|c|}{ Regulatory Frameworks } \\
\hline & EU & USA & South Africa & Kenya & Nigeria \\
\hline Definition & $\begin{array}{l}\text { A pesticide is } \\
\text { something that } \\
\text { prevents, destroys, or } \\
\text { controls a harmful } \\
\text { organism (pest) or } \\
\text { disease, or protects } \\
\text { plant or plant } \\
\text { products during } \\
\text { production, storage, } \\
\text { and transport. }\end{array}$ & $\begin{array}{l}\text { Pesticides derived } \\
\text { from such natural } \\
\text { materials as animals, } \\
\text { plants, bacteria, and } \\
\text { certain minerals. }\end{array}$ & $\begin{array}{l}\text { Any biological } \\
\text { remedy or mixture or } \\
\text { combination of any } \\
\text { substance excluding } \\
\text { any biological } \\
\text { remedy controlled } \\
\text { under the medicines } \\
\text { or the hazardous } \\
\text { substance act. }\end{array}$ & $\begin{array}{l}\text { Biological pest } \\
\text { control agents that } \\
\text { are naturally } \\
\text { occurring or } \\
\text { genetically modified } \\
\text { agents or derived } \\
\text { from } \\
\text { natural materials. }\end{array}$ & $\begin{array}{l}\text { Pesticides derived } \\
\text { from such natural } \\
\text { materials as animals, } \\
\text { plants, and } \\
\text { microorganisms. }\end{array}$ \\
\hline \multirow[t]{2}{*}{ Major Classification } & $\begin{array}{l}\text { Pesticides: } \\
\text { (Insecticides, } \\
\text { Fungicides, } \\
\text { Rodenticides, etc.) }\end{array}$ & $\begin{array}{l}\text { Biochemical, } \\
\text { Microbial } \\
\text { Plant Incorporated } \\
\text { Protectants. }\end{array}$ & $\begin{array}{l}\text { Microbial, } \\
\text { Biochemical and } \\
\text { Semiochemical, } \\
\text { Macrobial, } \\
\text { Enzymes, Hormones } \\
\text { and Plant extracts. }\end{array}$ & $\begin{array}{l}\text { Biochemical, } \\
\text { Microbial, } \\
\text { Macrobial. }\end{array}$ & $\begin{array}{l}\text { Biochemical, } \\
\text { Microbial, } \\
\text { Plant Incorporated } \\
\text { Protectants. }\end{array}$ \\
\hline & Data Requirements & & & & \\
\hline $\begin{array}{l}\text { Product Chemistry } \\
\text { (Including Identity, } \\
\text { Composition, } \\
\text { Analysis and certified } \\
\text { limits, } \\
\text { Physicochemical } \\
\text { properties) }\end{array}$ & $\checkmark$ & $\checkmark$ & $\checkmark$ & $\checkmark$ & $\checkmark$ \\
\hline $\begin{array}{l}\text { Risk Assessments } \\
\text { (Human Health } \\
\text { and Environmental) }\end{array}$ & $\checkmark$ & $\checkmark$ & $\begin{array}{l}\checkmark \text { (Accepts existing } \\
\text { scientific } \\
\text { toxicological data). }\end{array}$ & $\checkmark$ & $\checkmark$ \\
\hline Residue Data & $\checkmark$ & $\begin{array}{l}\checkmark \text { (Required if: } \\
\text { microbial } \\
\text { biopesticide (MBP) } \\
\text { has a significant } \\
\text { potential to produce } \\
\text { a mammalian toxin; } \\
\text { and if use pattern is } \\
\text { such that residues } \\
\text { may be present in or } \\
\text { on food or } \\
\text { feed crops). }\end{array}$ & $\checkmark$ & $\checkmark$ & $\checkmark$ \\
\hline $\begin{array}{l}\text { Efficacy } \\
\text { (Performance Data) }\end{array}$ & $\checkmark$ & $\begin{array}{l}\text { Not required unless } \\
\text { claims to control } \\
\text { public health pest. }\end{array}$ & $\checkmark$ & $\checkmark$ & $\checkmark$ \\
\hline $\begin{array}{l}\text { Quality Control } \\
\text { (Methods of Analysis, } \\
\text { Manufacturing, } \\
\text { Stability Test, } \\
\text { Determination of } \\
\text { shelf life) }\end{array}$ & $\checkmark$ & $\checkmark$ & $\checkmark$ & $\checkmark$ & $\checkmark$ \\
\hline
\end{tabular}

European Commission (EC), European Food Safety Authority (EFSA), Member/Rapporteur Member States (RMS), United States Environmental Protection Agency (USEPA), Department of Agriculture, Land Reform and Rural Development (DALRRD), Pest Control Products Board (PCPB), National Agency for Food and Drug Administration and Control (NAFDAC).

ii. Review of the Nigerian biopesticide regulations and guidelines:

The Nigerian biopesticide regulations/guidelines were reviewed to generate recommendations needed for amendment. The documents assessed were: Biopesticide Registration Regulations 2019, Guidelines for Issuance of Permit to Import Field Trials Samples (Doc. Ref. No: VMAP-GDL-016-06) and Guidelines for Listing as Pesticides, Agrochemicals, Fertilisers, Biopesticides and Bio-fertilisers Marketers (Doc. Ref. No: VMAP-GDL-016-05)-Table 2. 
Table 2. Outcome of the review of the Nigerian biopesticide regulations.

\begin{tabular}{lll}
\hline Regulations & Section & Regulation Comment \\
\hline & & $\begin{array}{l}\text { The Agency shall, from time } \\
\text { to time, publish the list of } \\
\text { registered biopesticides on the } \\
\text { Agency's official website, } \\
\text { notifying the registration of } \\
\text { a biopesticide. }\end{array}$ \\
Regulations 2019 & $4(5)$ &
\end{tabular}

Efficacy assessment of a biopesticide to be introduced into the market shall be carried out to ensure that biopesticide approved would be efficacious for its intended use.

Observation/Recommendations

Technically, specificity is important, the word "time to time" can be replaced with more specific words like: The Agency shall update the list of registered biopesticides following each approval (or de-registration) of a new biopesticide.

If the Agency is of the view that relevant data of good quality has been generated in other countries, then it may waive the requirement for local data generation, especially when importing from countries with similar environmental and climatic conditions.

The assessment shall be monitored by the Agency at an approved research institute(s).

A manufacturer or importer engaged in the manufacturing, importation, distribution, sale, or storage of biopesticide shall submit preliminary and final reports to the Agency of any adverse effect on non-target organism and environment, loss of effectiveness associated with biopesticide occurring in It is necessary to have a list of approved research institutes as an appendix. The needed capacities of the research institutes may also be stated to serve as a template for upcoming institutes.

Nigeria or elsewhere.

\section{Guidelines for Issuance of \\ Permit to Import Field Trials \\ Samples (Doc. Ref. No: \\ VMAP-GDL-016-06) [22]}

Guidelines for Listing as Pesticides, Agrochemicals, Fertilisers, Biopesticides, and Bio-fertilisers Marketers. (Doc. Ref. No: VMAP-GDL-01605) [22]
The trial should be carried out according to the approved protocol for experimental/efficacy trial.

Appointment and acceptance letters, passport photographs of the technical officer including all credentials (Degree, National Youth Service Corps (NYSC) certificates, etc.). The technical officer should have scientific background with minimum of Ordinary National Diploma or its equivalent.
It will be more appropriate to immediately notify the agency of any adverse effects on environment, human, and animal health. Submission of reports may come later. This is to ensure timely mitigation of any adverse impacts.

It is important to specify the approved protocols, e.g., OECD guidelines, etc.

Technical officer with relevant training in biotechnology, or biopesticide research and development, may also be considered in lieu of academic degree qualifications.

It is important to have a separate guideline for listing of biopesticide, different from other agrochemicals, such as fertilisers, pesticides, etc.

\section{iii. Review of the FAO pesticide risk assessment guidelines:}

Risk Assessment is a valuable tool in evaluating the potential for possible health and environmental effects of both new and existing biopesticides. The potential toxicity (hazard) and exposure scenarios help in determining the overall level of risk in a qualitative and/or quantitative manner.

The bridging risk assessment matrices in Tables 3 and 4 were developed following the review of pesticide risk assessment techniques of the FAO. This, if implemented, is expected to help speed up the evaluation and authorisation process for biopesticides in Nigeria. 
Table 3. Bridged risk assessment matrix for a microbial biopesticide.

\begin{tabular}{|c|c|c|c|}
\hline \multicolumn{4}{|c|}{ Reference Country Risk Assessment } \\
\hline \multirow{2}{*}{\multicolumn{2}{|c|}{$\begin{array}{l}\text { Assume that Toxicology is Similar ir } \\
\text { Two Situations }\end{array}$}} & Risk Considered & Risk Considered \\
\hline & & Acceptable & Unacceptable \\
\hline \multirow{8}{*}{$\begin{array}{l}\text { Local } \\
\text { Situation }\end{array}$} & Product Strain & Sufficiently similar to reference & Less similar, conduct local risk assessment \\
\hline & $\begin{array}{l}\text { Content of Relevant } \\
\text { Metabolites }\end{array}$ & $\begin{array}{l}\text { Complies with maximum limit as } \\
\text { Reference and no metabolites of } \\
\text { concern present }\end{array}$ & $\begin{array}{l}\text { Complies with maximum limit but shows } \\
\text { presence of metabolites of concern }\end{array}$ \\
\hline & $\begin{array}{l}\text { Content of Microbial } \\
\text { Contaminants }\end{array}$ & $\begin{array}{l}\text { Content complies with reference } \\
\text { using internationally approved } \\
\text { protocols }\end{array}$ & $\begin{array}{l}\text { Content complies with reference using } \\
\text { other protocols, conduct data integrity }\end{array}$ \\
\hline & Product Efficacy & Similar or better than reference & Lower than reference \\
\hline & Product Use Pattern & Similar to reference & Different from reference \\
\hline & $\begin{array}{l}\text { Product Withholding } \\
\text { periods (If any) }\end{array}$ & Similar to reference & Not similar, conduct residue analysis \\
\hline & $\begin{array}{l}\text { Human and } \\
\text { Environmental Exposures }\end{array}$ & Similar to reference & Different from reference \\
\hline & $\begin{array}{l}\text { Environmental } \\
\text { Conditions }\end{array}$ & Similar to reference & Different from reference \\
\hline
\end{tabular}

Table 4. Bridged risk assessment matrix for a biochemical biopesticide.

\section{Reference Country Risk Assessment}

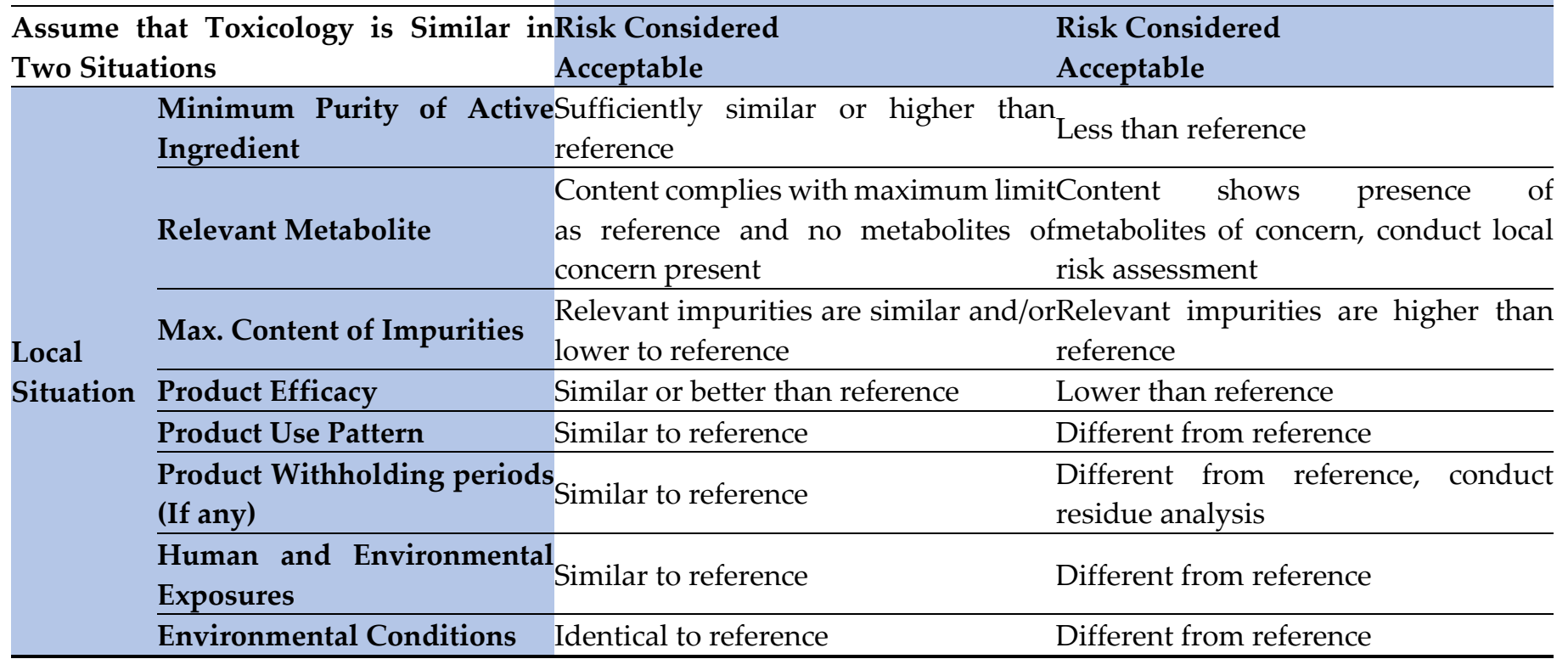

Sources: All information and documents reviewed were sourced online from the corresponding authority's website as listed in the reference lists.

3. Results

3.1. Comparative Assessments of the Biopesticide Regulatory Frameworks

An overview of the regulatory framework comparison between EU, USA, South Africa, Kenya, and Nigeria were summarised in Table 1. 


\subsection{Review of the Nigeria Biopesticide Regulations and Guidelines}

The observations made on the corresponding Nigeria biopesticide regulations and guidelines were shown in Table 2.

\section{Discussion}

\subsection{Definition and Classification of Biopesticides}

The definition of biopesticides varies between countries and it seems to influence their classification and regulatory mechanisms. The biopesticide definition adopted by the USEPA is quite similar to that of Nigeria [21,23]. This identical definition between the two might be responsible for the similarity in their classification (Table 1). Kenya defines biopesticides as biological pest control agents that are naturally occurring or genetically modified [24], while South Africa recognises biopesticides as any biological remedy or any mixture or combination of any substance or remedy intended or offered to be used for the destruction, control, repelling, attraction, or prevention of any undesired microbe, alga, nematode, fungus, insect, plant, vertebrate, invertebrate, or any product thereof [19]. Unlike Nigeria and the USA, South Africa and Kenya do not recognise Genetically Modified Organisms (GMOs) as a biopesticide category. Rather, they have adopted the Microbial, Macrobial, and Biochemicals classifications. However, South Africa includes Semiochemicals in its biochemicals class, and has a separate class for Enzymes, Hormones, and Plant Extracts. The EU does not recognise biopesticides as a separate regulatory category from conventional chemical pesticides. It considers biopesticides as Plant Protection Products (PPPs) of biological nature [25] whose classification is mostly based on target organisms. The EU's definition for biopesticides is the same for pesticides [26]. This different biopesticide classifications might be responsible for some of the challenges faced by companies in moving their products across jurisdictions.

\subsection{Overview of Data Requirements for Biopesticide Registration}

The baseline data requirements and general regulatory processes for the licensing of biopesticides in Nigeria are not substantially different from those in the other reviewed countries. Generally, the basic, and common, data required by most authorities relate to product chemistry, health and environmental risk assessments, efficacy, quality control and residue information (Table 1). Even though product performance data must be developed for all biopesticides, the USEPA does not typically require applicants to submit efficacy data unless the product bears a claim to control public health [27]. It also requires residue data for microbial pesticides only if such products have significant potential to produce a mammalian toxin, and if the use pattern is such that residues may be present in or on food/feed crops [27]. Contrary to the USEPA position, efficacy and residue data are considered vital components for the registration of biopesticides in Nigeria, South Africa, Kenya, and the EU. However, the South African regulatory authority may issue provisional registration for applicants with toxicological assessment reports containing new active ingredients, which are already registered in developed countries (like the US, UK, EU, Australia or Japan) alongside a toxicological assessment from an independent accredited toxicologist in South Africa [19]. Nigeria, on the other hand may, considers provisional approval for applicants after successful field trial assessment for one crop season. Data on human health and environmental risk assessments, product chemistry, and quality control are required by all the countries and regions examined.

\subsection{Overview of Regulatory Framework for Biopesticides}

The main aim of regulation is to ensure the safety of humans, animals and the environment. Regulation should not in any way be seen as a barrier to the development and commercialisation of biopesticides but rather, as a scientific process, tool, or path to ensure that all biopesticides placed on the market are safe, efficacious, and do not pose unacceptable risks to humans, animals and the environment. Different regulatory frameworks exist for the regulation of biopesticides. The EU has three main regulatory authorities while 
the USA, South Africa, Kenya, and Nigeria have one each (Table 1). The EU adopted the conventional pesticide regulatory model for the regulation of its biopesticides while Nigeria and the US have customised their regulations. Biopesticides that fulfil the EU low-risk criteria are, however, considered as low-risk pesticides and hence benefit from low-risk incentives, which include faster authorisation processes and a longer license validity period compared to chemical pesticides [28]. Applicants seeking approval or registration for PIPs as biopesticides in South Africa, Kenya and Nigeria must first comply with the provisions of the national GMO Act before applying to the biopesticide regulatory authorities for registration. However, USEPA self-regulates PIPs and ensures that they meet federal safety standards before approval [29]. Plant Protection Products containing GMOs in the EU are regulated in accordance with Directive 2001/18/EC in addition to the regulations governing placement of PPPs on the market [17]. The license validity for biopesticides varies across the examined countries: EU (15 years), US (15 years), South Africa (3 years), Kenya ( 3 years), and Nigeria ( 5 years). The need for license renewal enables regulatory authorities to determine whether license holders are still complying with the approval conditions. License validity periods appear to be longer in developed countries where there may be, arguably, a higher commitment to regulatory compliance.

\subsection{Overview of Risk Assessment}

Complete local Risk Assessments (RA) are sometimes time consuming and expensive. Regulators may therefore need to consider the bridging and equivalence approach. This approach is suitable if it can be determined or established that the data or dossier submitted for evaluation of local (new) biopesticide products is similar to a registered reference product-in terms of toxicological profiles, impurities, and physicochemical properties [30]. Bridging often requires good knowledge of the principles and procedures of risk assessment, bearing in mind that a detailed local exposure estimation or full-fledged assessment of toxicity data is not required. When clear and unequivocal conclusions are achieved in a bridging process, further local assessments are no longer needed, but if otherwise, bridging may still be employed to facilitate the overall risk assessments by focusing the local risk assessment technique on specific issues of concern [31]. Bridging assumes that since the reference product is a registered biopesticide, the quality, efficacy, and risks are already acceptable in the reference country and it is, therefore, an obligation of the local authorities to decide if the same risk will be acceptable in their own situation. The product use pattern, application rate, timing, withdrawal periods, potential adverse effects, and environmental conditions are important factors when considering the bridging approach [30]. Allergenicity, genotoxicity, and biological properties are also significant when assessing potential risks. It should however be noted that bridging will not be possible if the characteristics of the biopesticide products deviate too much from the reference product or if the exposure scenarios between the two situations cannot be compared. Bridging can only be done if the active ingredient is the same for the reference and local product [32]. If risk assessments indicate a high likelihood of hazard, additional testing maybe required and approval for use may then be restricted or completely rejected.

The tiered approach assists regulatory agencies to make scientifically sound regulatory RA decisions in a timely and cost-effective manner. Tiered testing entails structuring the assessments or evaluation methods in such a way that unnecessary or more complicated lines of assessment are minimised or completely avoided. It is designed to first consider unrealistic 'worst case' scenarios and if these are unlikely (do not pose any hazard), then further testing or RA is not necessary. However, if Tier-1 screening indicates that unacceptable effects are possible or probable, (i.e., fail to prove adequate certainty of acceptable risks), then further testing must be carried out [33]. For example, if a biopesticide product is formulated with inert substances or materials of no toxicological concern, RA can reasonably be based on the active ingredients alone as it represents the worst-case scenario. Also, RA data may only be required for the end use products if no scientific distinction exists between active ingredients and the final product. The tiered approach 
has the goal of achieving adequate certainty of acceptable risk. It should be noted that uncertainty and variability are critical factors when conducting RA. Since uncertainty stems from lack of knowledge, it cannot be eliminated but can rather be minimised, characterised, and managed via the use of more reliable data. Variability, on the other hand, cannot be minimised or reduced as it is an inherent characteristic of a population.

\section{Recommendations for Sustainable Regulation of Biopesticides in Nigeria}

The following recommendations were developed to promote sustainable regulation of biopesticides in Nigeria.

\subsection{Amendment of the Current Biopesticide Regulations}

The sections of the Nigeria biopesticide regulations and guidelines identified for amendments are highlighted in Table 2. Additionally, the separate/standalone document suggested for the listing of biopesticides (Section 2.2.6 in Table 2), will allow for improved data requirements as new knowledge becomes available. It will also not in any way be seen to undermine the integrity or assume less priority for the other regulated agrochemical products.

\subsection{Checklist for Evaluation by Equivalence}

The checklist in Table 5 was developed using the template from the FAO pesticide tool kit [30] and the Kenya guidance on dossier for pest control products [32]. This checklist will speed up the initial document evaluation and decision-making process by identifying potential areas of concern at the early stages of the application screening process.

Table 5. Checklist for biopesticide evaluation by equivalence.

\begin{tabular}{|c|c|c|c|c|}
\hline \multicolumn{5}{|c|}{ Checklist: Evaluation by Equivalence } \\
\hline \multicolumn{3}{|c|}{ Product Name: } & \multicolumn{2}{|c|}{ Registration File Number: } \\
\hline \multicolumn{2}{|c|}{ Name of the Assessor: } & \multicolumn{3}{|c|}{ Date of the Assessment: } \\
\hline \multicolumn{5}{|c|}{$\begin{array}{c}\text { Comparison of Parameters for the Local Situation Under Review and a Reference Country } \\
\text { Describe/Quantify the } \\
\text { Parameter for: }\end{array}$} \\
\hline \multicolumn{2}{|c|}{ Parameter } & $\begin{array}{l}\text { Local Situation } \\
\text { (Application) }\end{array}$ & $\begin{array}{c}\text { Reference } \\
\text { Country } \\
\text { (Registration) }\end{array}$ & Remarks \\
\hline \multicolumn{5}{|c|}{ Country } \\
\hline \multirow[t]{2}{*}{1} & Country & & & \\
\hline & Applicant/registrant & & & \\
\hline 2 & $\begin{array}{l}\text { Name and address of } \\
\text { applicant/registrant }\end{array}$ & & & \\
\hline 3 & Name of manufacturer & & & \\
\hline \multirow[t]{2}{*}{4} & $\begin{array}{l}\text { Registration status in } \\
\text { reference country }\end{array}$ & & & \\
\hline & Pesticide product & & & \\
\hline 5 & Product name & & & \\
\hline 6 & $\begin{array}{l}\text { Active ingredient } \\
\text { common name }\end{array}$ & & & \\
\hline
\end{tabular}


Table 5. Cont.

\begin{tabular}{|c|c|c|c|c|}
\hline \multicolumn{5}{|c|}{ Checklist: Evaluation by Equivalence } \\
\hline \multicolumn{2}{|c|}{ Product Name: } & \multicolumn{3}{|c|}{ Registration File Number: } \\
\hline \multicolumn{2}{|c|}{ Name of the Assessor: } & \multicolumn{3}{|c|}{ Date of the Assessment: } \\
\hline \multicolumn{5}{|c|}{$\begin{array}{c}\text { Comparison of Parameters for the Local Situation Under Review and a Reference Country } \\
\text { Describe/Quantify the } \\
\text { Parameter for: }\end{array}$} \\
\hline \multicolumn{2}{|r|}{ Parameter } & $\begin{array}{l}\text { Local Situation } \\
\text { (Application) }\end{array}$ & $\begin{array}{c}\text { Reference } \\
\text { Country } \\
\text { (Registration) }\end{array}$ & Remarks \\
\hline 7 & \multicolumn{4}{|l|}{ Formulation type } \\
\hline 8 & \multicolumn{4}{|l|}{$\begin{array}{l}\text { Active ingredient } \\
\text { concentration in the } \\
\text { product }(\mathrm{cfu} / \mathrm{g} \text { or } \mathrm{mL}, \mathrm{g} \\
\text { a.i/ } \mathrm{kg})\end{array}$} \\
\hline 9 & \multicolumn{3}{|l|}{$\begin{array}{l}\text { Declaration by applicant } \\
\text { that the product is } \\
\text { identical or equivalent to } \\
\text { the one in the } \\
\text { reference country }\end{array}$} & \\
\hline \multicolumn{5}{|c|}{ If not: } \\
\hline 10 & \multicolumn{4}{|l|}{$\begin{array}{l}\text { Active ingredient } \\
\text { manufacturing source }\end{array}$} \\
\hline 11 & \multicolumn{4}{|l|}{$\begin{array}{l}\text { Min. Purity of A.I } \\
\text { (biochem/semio) }\end{array}$} \\
\hline 12 & \multicolumn{4}{|l|}{$\begin{array}{l}\text { Max. Content of } \\
\text { relevant impurities }\end{array}$} \\
\hline 13 & \multicolumn{4}{|l|}{$\begin{array}{l}\text { Impurities from } \\
\text { Manufacturing }\end{array}$} \\
\hline 14 & \multicolumn{4}{|l|}{ Strain (MCP) } \\
\hline 15 & \multicolumn{4}{|l|}{$\begin{array}{l}\text { Max. Limit of } \\
\text { relevant metabolites }\end{array}$} \\
\hline 16 & \multicolumn{4}{|l|}{$\begin{array}{l}\text { Content of } \\
\text { microbial contaminant }\end{array}$} \\
\hline 17 & \multicolumn{4}{|l|}{ Efficacy } \\
\hline 18 & \multicolumn{4}{|l|}{ Toxicological properties } \\
\hline 19 & \multicolumn{4}{|l|}{$\begin{array}{l}\text { Co-formulants triggering } \\
\text { a hazard classification }\end{array}$} \\
\hline 20 & \multicolumn{4}{|c|}{ Conclusion with respect to the pesticide product: } \\
\hline & \multicolumn{4}{|l|}{ Use } \\
\hline 21 & \multicolumn{4}{|l|}{ Crop or use situation } \\
\hline 22 & \multicolumn{4}{|l|}{ Pest } \\
\hline 23 & \multicolumn{4}{|l|}{ Dose rate (g a.i./ha) } \\
\hline 24 & \multicolumn{4}{|l|}{$\begin{array}{l}\text { Number of applications } \\
\text { per growing season }\end{array}$} \\
\hline
\end{tabular}


Table 5. Cont.

\begin{tabular}{|c|c|c|c|c|}
\hline \multicolumn{5}{|c|}{ Checklist: Evaluation by Equivalence } \\
\hline \multicolumn{2}{|c|}{ Product Name: } & \multicolumn{3}{|c|}{ Registration File Number: } \\
\hline \multicolumn{2}{|c|}{ Name of the Assessor: } & \multicolumn{3}{|c|}{ Date of the Assessment: } \\
\hline \multicolumn{5}{|c|}{$\begin{array}{c}\text { Comparison of Parameters for the Local Situation Under Review and a Reference Country } \\
\text { Describe/Quantify the } \\
\text { Parameter for: }\end{array}$} \\
\hline \multicolumn{2}{|r|}{ Parameter } & $\begin{array}{l}\text { Local Situation } \\
\text { (Application) }\end{array}$ & $\begin{array}{l}\text { Reference } \\
\text { Country } \\
\text { (Registration) }\end{array}$ & Remarks \\
\hline 25 & \multicolumn{4}{|l|}{ Withholding period } \\
\hline 26 & \multicolumn{4}{|c|}{ Conclusion with respect to the use: } \\
\hline \multicolumn{5}{|c|}{ Human health risks } \\
\hline 27 & \multicolumn{4}{|l|}{$\begin{array}{l}\text { Use restrictions (human } \\
\text { health) }\end{array}$} \\
\hline 28 & \multicolumn{4}{|l|}{$\begin{array}{l}\text { Required/ } \\
\text { recommended PPE }\end{array}$} \\
\hline 29 & \multicolumn{4}{|l|}{$\begin{array}{l}\text { Level of } \\
\text { training/experience } \\
\text { of operator }\end{array}$} \\
\hline 30 & \multicolumn{4}{|c|}{$\begin{array}{l}\text { Conclusion with respect to the human health risks: Risks similar or less when compared to the } \\
\text { reference country: }\end{array}$} \\
\hline & \multicolumn{4}{|l|}{ Environmental risks } \\
\hline 31 & \multicolumn{4}{|l|}{$\begin{array}{l}\text { Use restrictions } \\
\text { (environment) }\end{array}$} \\
\hline 32 & \multicolumn{4}{|l|}{ Rainfall, temperature, soil } \\
\hline 33 & \multicolumn{4}{|l|}{$\begin{array}{l}\text { Sensitive } \\
\text { ecosystems/organisms }\end{array}$} \\
\hline 34 & \multicolumn{4}{|c|}{ Conclusion with respect to the environmental risks: } \\
\hline 35 & \multicolumn{4}{|l|}{ Overall conclusions: } \\
\hline
\end{tabular}

This checklist was adapted from the FAO pesticide registration tool kit [30] and Kenya guidance on dossier evaluation [32].

\subsection{Regional Data Sharing and Harmonisation of the Regulatory Process}

Data sharing and joint review processes amongst other African countries (especially those with similar environmental condition) will help promote simultaneous access to new knowledge, improved technical networking initiatives, and increased efficiency of the regulatory process. Harmonisation of biopesticide regulations will also promote mutually comparable standards, protocols, norms, and ease transboundary trade either within the African region or across the continent.

\subsection{Bridged Risk Assessment Matrices for Microbial and Biochemical Biopesticides}

Two bridged risk assessment matrices were developed to help improve scientific regulatory decision making in a more timely and effective manner, viz:

(a) Bridged risk assessment matrix for a microbial biopesticide as shown in Table 3

(b) Bridged risk assessment matrix for a biochemical biopesticide as shown in Table 4

\subsection{Capacity Building and Public Awareness}

Capacity building of regulators, risk managers, and increased public awareness on the benefits of biopesticides will help promote the effective regulation of biopesticides. 


\section{Summary}

Biopesticides are known to include a wide range of both living and non-living natural substances that vary widely in their bioproperties, mode of action, composition, and toxicities-hence the need for a sustainable regulatory approach for maximum protection of animal and human health and the environment. The different biopesticide regulatory frameworks and variations in the data requirements across countries and regions are some of the leading factors inhibiting the sustainable development and transboundary trade of biopesticides.

The regulatory challenges facing the development and commercialisation of biopesticide products in Nigeria were identified to include protracted or extensive field trials and risk assessment methods and inability of applicants to fulfil the GMO requirements for registration of PIPs. Low public awareness and high market cost of biopesticides also inhibits its commercialisation in the region.

Although the biopesticide regulatory system in Nigeria is not significantly different from those in other countries, amendment of the current Nigeria biopesticide regulations, use of technical checklists, and bridged risk assessment matrices will enhance the scientific decision-making process. Data (Efficacy and Toxicity) sharing and harmonisation of regulatory processes between countries/regions (especially those with similar ecologic conditions) will undoubtedly promote mutually comparable standards, inter data acceptability, norms, and protocols for sustainable regulation.

It is pertinent to note that a no risk situation does not exist, not even for biopesticides. Tiered RA approaches and data waivers should always be substantiated with sound scientific and technical arguments. Non-regulatory factors, such as political, social, and societal pressure also influence the development and commercialisation of biopesticides. Capacity building of regulators, developers, risk managers, and public awareness will help smooth the path of transboundary trade and easy, effective commercialisation across regions.

Author Contributions: Study design: D.N. and C.A.A.; research and analysis: C.A.A.; supervision: D.N.; writing: C.A.A. with comments from D.N., E.N., and C.O.O. All authors have read and agreed to the published version of the manuscript.

Funding: This research was funded by the International Centre for Genetic Engineering and Biotechnology (ICGEB), Cape Town, South Africa under the ICGEB Arturo Falaschi Short-term Postdoctoral Fellowship Programme (F/NGA20-04).

Data Availability Statement: Data on registered biopesticide Kenya: The biopesticide registered data presented in this study are openly available at https:/ / www.pcpb.go.ke/biopesticides-on-crops / (accessed on 24 December 2021); South Africa: Data was available from a third party at https: / / sabo.org.za/ (accessed on 24 December 2021); Nigeria: Data was available from a third party at www.nafdac.gov.ng (accessed on 24 December 2021).

Acknowledgments: ICGEB: Rufus Ebegba (National Biosafety Management Agency, Nigeria), Tunde Shigbeku (NAFDAC, Nigeria), Grace Adetoye (NAFDAC, Nigeria), Tobi Okuwoga (NAFDAC, Nigeria) and Karen Muirhead (ICGEB, South Africa).

Conflicts of Interest: The authors declare no conflict of interest. The funders had no role in the design of the study; in the collection, analyses, or interpretation of information and data; in the writing of the manuscript, or in the decision to publish the results.

\section{References}

1. Ndolo, D.; Njuguna, E.; Adetunji, C.O.; Harbor, C.; Rowe, A.; Den Breeyen, A.; Sangeetha, J.; Singh, G.; Szewczyk, B.; Anjorin, T.S.; et al. Research and development of biopesticides: Challenges and prospects. Outlooks Pest Manag. 2019, 30, 267-276. [CrossRef]

2. WHO (World Health Organisation). Guidelines for the Registration of Microbial, Botanical and Semiochemical Pest Control Agents for Plant Protection and Public Health Uses. 2017. Available online: https://www.who.int/publications/i/item/WHOHTM-NTD-WHOPES-2017.05 (accessed on 24 September 2021). 
3. OECD (Organisation for Economic Cooperation and Development). Joint Meeting of the Chemicals Committee and the Working Party on Chemicals, Pesticides and Biotechnology. Working Document on the Evaluation of Microbials for Pest Control JT03257921. 2008. Available online: https://www.oecd.org/env/ehs/pesticides-biocides/41946259.pdf (accessed on 24 September 2021).

4. Balog, A.; Hartel, T.; Loxdale, H.D.; Wilson, K. Differences in the progress of the biopesticide revolution between the EU and other major crop-growing regions. Pest Manag. Sci. 2017, 73, 2203-2208. [CrossRef] [PubMed]

5. Ivase, T.J.-P.; Nyakuma, B.B.; Ogenyi, B.U.; Balogun, A.D.; Hassan, M.N. Current status, challenges, and prospects of biopesticide utilisation in Nigeria. Acta Univ. Sapientiae Agric. Environ. 2017, 9, 95-106.

6. Glare, T.R.; Gwynn, R.L.; Moran-Diez, M.E. Development of biopesticides and future opportunities. Methods Mol. Biol. 2016, 1477, 211-221. [PubMed]

7. Czaja, K.; Góralczyk, K.; Struciński, P.; Hernik, A.; Korcz, W.; Minorczyk, M.; Łyczewska, M.; Ludwicki, J.K. BiopesticidesTowards increased consumer safety in the European Union. Pest Manag. Sci. 2015, 71, 3-6. [CrossRef] [PubMed]

8. Chandler, D.; Bailey, A.S.; Tatchell, G.M.; Davidson, G.; Greaves, J.; Grant, W.P. The development, regulation and use of biopesticides for integrated pest management. Philos. Trans. R. Soc. B Biol. Sci. 2011, 366, 1987-1998.

9. Vinale, F.; Sivasithamparam, K.; Ghisalberti, E.L.; Marra, R.; Woo, S.L.; Lorito, M. Trichoderma-plant-pathogen interactions. Soil. Biol. Biochem. 2008, 40,1-10.

10. Harman, G.E. Trichoderma-Not just for biocontrol anymore. Phytoparasitica 2011, 39, 103-108. [CrossRef]

11. Verma, M.; Brar, S.K.; Tyagi, R.D.; Surampalli, R.Y.; Valéro, J.R. Antagonistic fungi, Trichoderma spp.: Panoply of biological control. Biochem. Eng. J. 2007, 37, 1-20.

12. Tewari, S.; Arora, N.K. Fluorescent Pseudomonas sp. PF17 as an efficient plant growth regulator and biocontrol agent for sunflower crop under saline conditions. Symbiosis 2016, 68, 99-108.

13. OECD (Organisation for Economic Cooperation and Development). Joint Meeting of the Chemicals Committee and the Working Party on Chemicals, Pesticides and Biotechnology. OECD Series on Pesticides; Number 18; Guidance for Registration Requirements for Microbial Pesticides; JT00144667. 2003. Available online: https://www.oecd.org/env/ehs/pesticides-biocides/288884 46.pdf (accessed on 20 September 2021).

14. NAFDAC (National Agency for Food and Drug Administration and Control). Available online: https://www.nafdac.gov.ng/ (accessed on 23 September 2021).

15. SABO (South African Bioproducts Organisation). Available online: https://sabo.org.za (accessed on 23 September 2021).

16. PCPB (Pest Control Products Board). Registered Biopesticides for Use in Crop Production. Available online: https: / /www.pcpb. go.ke/biopesticides-on-crops / 05 (accessed on 23 September 2021).

17. EC (European Commission). Regulation (EC) No 1107/2009 of the European parliament and of the council of 21 October 2009 concerning the placing of plant protection products on the market and repealing council directives 79/117/EEC and 91/414/EEC Off. J. Eur. Union 2009, 309, 1-50.

18. eCFR (Electronic Code of Federal Regulations). Title 40. Protection of Environment. Available online: https: / www.ecfr.gov / current/title-40\#0 (accessed on 23 September 2021).

19. DAFF (Department of Agriculture, Fisheries and Forestry). Guidelines on the Data Required for Registration of Biological/Biopesticides Remedies in South Africa. 2015. Available online: https:/ / www.nda.agric.za/doaDev/sideMenu/ActNo36 1947 / AIC /Guidelines\%20for\%20Registration\%20of\%20Biological\%20Remedies\%202015\%20Registrar\%20of\%20Act\%2036\%2 0of\%201947.pdf (accessed on 23 September 2021).

20. Pest Control Products Act. Available online: http://kenyalaw.org/kl/fileadmin/pdfdownloads/Acts/PestControlProductsAct_ _Cap346_.pdf. (accessed on 23 September 2021).

21. NAFDAC (National Agency for Food and Drug Administration and Control). Biopesticide Registration Regulations 2019 Available online: https:/ / www.nafdac.gov.ng/wp-content/uploads/Files/Resources/Regulations/New_Draft_Regulations / Bio-Pesticides-Registraton-Regulations.pdf (accessed on 4 August 2021).

22. NAFDAC (National Agency for Food and Drug Administration and Control). Guidelines. Available online: https://www.nafdac. gov.ng/resources/guidelines/ (accessed on 24 September 2021).

23. USEPA (United States Environmental Protection Authority). What Are Biopesticides? Available online: https://www.epa.gov/ ingredients-used-pesticide-products/what-are-biopesticides (accessed on 24 September 2021).

24. Wabule, M.N.; Ngaruiya, P.N.; Kimmins, F.K.; Silverside, P.J. Registration for biocontrol agents in Kenya. In Proceedings of the Pest Control Products Board/Kenya Agricultural Research Institute/Department for International Development Crop Protection Programme Workshop, Nakuru, Kenya, 14-16 May 2003; 2004. Available online: https:/ /assets.publishing.service.gov.uk/media/ 57a08cc040f0b649740013fe/R7299Registration.pdf (accessed on 5 August 2021).

25. European Commission (EC). Official Website. Available online: https://ec.europa.eu/info/index_en (accessed on 24 September 2021).

26. European Commission (EC). Pesticides. Available online: https://ec.europa.eu/food/plants/pesticides_en\#ecl-inpage-464 (accessed on 24 September 2021).

27. eCFR (Electronic Code of Federal Regulations): Title 40, Part 158—Data Requirements for Pesticides. Available online: https: / / www.ecfr.gov / current/title-40/chapter-I/subchapter-E/part-158\#158.2010 (accessed on 24 September 2021).

28. EC (European Commission). Pesticides Explained-What Are Pesticides? Available online: https://ec.europa.eu/assets/sante/ food/plants/pesticides/lop/index.html (accessed on 24 September 2021). 
29. USEPA (United States Environment Protection Authority). Overview of Plant Incorporated Protectants. Available online: https: //www.epa.gov/regulation-biotechnology-under-tsca-and-fifra/overview-plant-incorporated-protectants\#Overview (accessed on 24 September 2021).

30. FAO (Food and Agriculture Organisation of the United Nations). Registration by Analogy-Pesticide Registration Toolkit. Available online: http:/ / www.fao.org/pesticide-registration-toolkit/registration-tools/registration-strategies/registration-byanalogy/en/ (accessed on 24 September 2021).

31. FAO (Food and Agriculture Organisation of the United Nations). Pesticide Registration Toolkit. General Guidance on Bridging of Pesticide Risk Assessments. Available online: http://www.fao.org/pesticide-registration-toolkit/registration-tools/ assessment-methods/general-guidance-on-bridging-of-pesticide-risk-assessments-introduction-and-principles/en// (accessed on 25 September 2021).

32. Ter Horst, M.M.S.; Aluoch, J.A.; Barasa, M.W.; Bosman-Hoefakker, S.; Broeders, J.; Van Etten, J.; De Jong, E.; Ngaruiya, P.N.; Steenbergh, A.; Van der Valk, H.; et al. Guidance on Dossier Evaluation for the Registration of Pest Control Products in Kenya. Wageningen, Wageningen Environmental Research, Report 2979. 2019. Available online: https://edepot.wur.nl/510074 (accessed on 24 September 2021).

33. OECD (Organisation for Economic Cooperation and Development). Joint Meeting of the Chemicals Committee and the Working Party on Chemicals, Pesticides and Biotechnology. Considerations for the Environmental Risk Assessment of the Application of Sprayed or Externally Applied ds-RNA-Based Pesticides. Series on Pesticides No. 104 JT03465823. 2020. Available online: https: / / www.oecd.org/officialdocuments / publicdisplaydocumentpdf/?cote=env /jm/mono(2020)26\&doclanguage=en (accessed on 24 September 2021). 